\title{
Comparative to study of the different intra row spacing of mechanized rice transplanting in fields of Chittoor district
}

\author{
M. NAGA JYOTHI AND G. MURALEE KRISHNA
}

Received : 31.07 .2017 ; Revised : 25.08.2017; Accepted : 11.09 .2017

See end of the Paper for authors' affiliation Correspondence to :

M. NAGA JYOTHI College of Agricultural Engineering, MADAKASIRA (A.P.) INDIA
-ABSTRACT : Rice is one of the most important cereals that hold the key for food security. SRI has reached certain level of acceptance among the research and scientific community in major rice producing countries. The SRI method of rice cultivation involves planting single seedling in wider row spacing i.e., $25 \times 25 \mathrm{~cm}$, which involves more labour intensive and laborious process. Hence, the present study was conducted with an objective to compare the mechanized rice transplanting with different intra row spacing with mechanized rice transplanter method with SRI and normal method of rice cultivation. The study was conducted with four treatments i.e., $\mathrm{T}_{1}-\mathrm{Machine}$ transplanting at spacing of $(30 \times 14 \mathrm{~cm}), \mathrm{T}_{2}-$ Machine transplanting at spacing of $(30 \mathrm{x} 18 \mathrm{~cm}), \mathrm{T}_{3}$ - Machine transplanting at spacing of $(30 \times 20 \mathrm{~cm}), \mathrm{T}_{4}$ - Machine transplanting at spacing of $(30 \mathrm{x}$ $22 \mathrm{~cm})$ and $\mathrm{T}_{5}$ - Manual transplanting at spacing of $(20 \times 15 \mathrm{~cm})$ (control). The study indicated that mechanized transplanting with rice transplanter adopting highest yield of $(30 \times 20 \mathrm{~cm})$ row spacing recorded more 10.00 per cent more yield, when compared to $30 \mathrm{x} 18 \mathrm{~cm}$ ) method of planting. Mechanised paddy farmers were able to secure a net income Rs. 1.81/- per every rupee of expenditure. While, the convectional paddy farmers realized Rs. 1.42/-.

- KEY WORDS : Mechanised system of rice intensification with SRI principles, Plant height, Economic

- HOW TO CITE THIS PAPER : Jyothi, M. Naga and Krishna, G. Muralee (2017). Comparative to study of the different intra row spacing of mechanized rice transplanting in fields of Chittoor district. Internat. J. Agric. Engg., 10(2) : 526-530, DOI: 10.15740/HAS/IJAE/10.2/526-530. 